\title{
THERMAL EVIDENCE OF THE INVASION OF A STINGLESS BEE NEST BY A MAMMAL
}

\author{
HILÁRIO, S. D. ${ }^{1}$ and IMPERATRIZ-FONSECA, V. L. ${ }^{2}$ \\ ${ }^{1}$ Departamento de Zoologia, Instituto de Biociências, Universidade de São Paulo, Rua do Matão, \\ tr. 14, n. 101, Cidade Universitária, CEP 05508-900, São Paulo, Brazil \\ ${ }^{2}$ Departamento de Ecologia, Instituto de Biociências, Universidade de São Paulo, \\ CEP 05508-900, São Paulo, Brazil \\ Correspondence to: Sergio Dias Hilário, Departamento de Zoologia, Instituto de Biociências, Universidade de São \\ Paulo, Rua do Matão, tr. 14, n. 101, Cidade Universitária, CEP 05508-900, São Paulo, Brazil, \\ e-mail: sedilar@usp.br \\ Received Juny 5, 2002 - Accepted September 12, 2002 - Distributed August 31, 2003
}

(With 2 figures)

\begin{abstract}
Melipona bicolor, an inhabitant of the Atlantic Rainforest, nidifies in hollows of live or dead trees. In order to study thermoregulation of a nest of this species, a temperature data logger was installed inside a hollow tree. After this, an intruder dug a hole, invaded the nest, and probably consumed its honey, pollen and bees, having remained there during three days. Thermal evidence and its behavior allowed the delimitation of a small number of suspects, wich we analized here. The intruder was a small mammal, predominantly nocturnal, that takes shelter in burrows, probably the yellow armadillo (Euphractus sexcinctus). Other evidence, if collected immediately after invasion, could precisely indicate precisely the species.
\end{abstract}

Key words: temperature, thermoregulation, stingless bees, mammal, heat production.

\section{RESUMO}

\section{Evidência térmica da invasão de um ninho de abelhas sem ferrão por um mamífero}

Melipona bicolor, uma habitante de nossa Mata Atlântica, nidifica em ocos de árvores vivas ou mortas. Com a finalidade de estudar a termorregulação de um ninho dessa espécie, um data logger de temperatura foi instalado no interior de um oco de árvore. Depois disso, um intruso cavou o solo, invadiu o ninho e provavelmente consumiu seu mel, pólen e abelhas, tendo ali permanecido durante três dias. Evidência térmica e comportamento permitiram delimitar um número pequeno de suspeitos, os quais analisamos aqui. $\mathrm{O}$ intruso foi um pequeno mamífero, predominantemente noturno, que se abriga em tocas, provavelmente o tatu-peludo. Outras evidências, se coletadas imediatamente após a invasão, indicariam exatamente a espécie do intruso.

Palavras-chave: temperatura, termorregulação, abelhas sem ferrão, mamífero, produção de calor.

\section{INTRODUCTION}

Several animals shelter in cavities within the soil, trees, or other substrates, seeking protection from predators, water loss, or adverse weather conditions. Moreover, they take into account the availability of potential mates and/or food. Commonly, there is a succession of animals from different taxa inside such a shelter. For instance,
Darchen (1973) reported that bird species excavate arboreal termites' nests. After bird departure, stingless bees nest there; sometimes they are mutualists with the termites.

Bees shelter mainly in preexisting cavities, such as hollow trees, nests abandoned by other animals, and clefts or spaces between rocks. Other bees build nests in open areas, under canopy or rocks (Castro, 2001). 
Solitary and social bees have relationships of parasitism, mutualism, commensalisms, and predation with many organisms of the animal kingdom, from nematodes to mammals (Roubik, 1989; Nogueira-Neto, 1997). Predators consume honey, pollen, and bees, or simply take advantage of the microclimate inside their nests.

The objective of this work was to analyze evidence left by an intruder that probably destroyed a natural nest of the stingless bee Melipona bicolor and consumed its bees.

\section{MATERIAL \& METHODS}

A data logger $\mathrm{HOBO}$ with two temperature channels $\left( \pm 0.3^{\circ} \mathrm{C}\right)$ was installed in a natural nest of the eusocial stingless bee Melipona bicolor bicolor in order to study thermoregulatory behavior. The natural nest was located in Atlantic Rainforest in Cunha, SP $\left(23^{\circ} 05^{\prime}\right.$ 'S, $\left.44^{\circ} 55^{\prime} \mathrm{W}\right)$. The data logger had two temperature sensors: one in the main body of the device, located outside the tree and measuring the external temperature; the other is in the cable tip, enabling its installation inside a cavity so as to measure the internal temperature. The temperatures were recorded at 30-minute intervals. Luminosity data were obtained from the schedules of civil twilight beginning and end, available at the U. S. Naval Observatory: $<$ http://aa.usno.navy.mil/AA/data>.

Around two months after the data logger installation, an intruder dug a hole, invaded the bee nest, and probably consumed its bees. In the results section, we will demonstrate that this intruder was a mammal. On the American continent, there are several mammals that are bee predators or honey robbers: tayras, kinkajous, coatis, tamanduas, armadillos, grisons, bears, skunks, opossums, and rats (Roubik, 1989; Nogueira-Neto, 1997). We analyzed mammal species inhabiting the region of Cunha (SP). Scientific names were obtained from Wilson \& Reeder (1993); data on size, habit, behavior, geographic distribution, and English names were obtained from Grzimek (1990) and Emmons \& Feer (1990).

Data for three days of internal and external temperature before, during, and after the invasion, were compared through two-tailed paired-sample $t$-test (Zar, 1999). The differences between the internal and external temperatures allowed comparing the three situations through two-tailed paired-sample $t$ test.
In order to calculate the rate of heat production $(M)$, it was necessary to maintain constant the temperature of the mammal. We used the formula $M=C \cdot \Delta T$, where $C$ is thermal conductance and $\Delta T$, the thermal gradient (Willmer et al., 2000). For these calculations, we considered that the sensor was next to the body of the mammal. The thermal conductance was obtained through the equation $C=0.760 \cdot B M^{-0.426}$, where $B M$ is the body mass of the mammal (Bradley \& Deavers, 1980). The thermal gradient is the difference between the internal and external temperatures of the hollow tree during the invasion. Because after intruder exit there was a significant temperature difference (see results), this difference was deducted from the thermal gradient. Two thermal gradients were calculated, one mean $( \pm$ SD) for the day and the other mean for night ( \pm SD). We simulated mass values from $750 \mathrm{~g}$ to 2000 $\mathrm{g}$, based on the available space of the hollow (tree diameter).

\section{RESULTS}

The living tree, in which the bee nest was located, was approximately $46.0 \mathrm{~cm}$ in diameter at ground level and 14 meters high. The intruder gained access to the nest after digging a hole about 12.0 $\mathrm{cm}$ in diameter, at the tree base, exactly at the bee nest entrance. This tree is part of a dense forest with watercourses and waterfalls.

The Fig. 1 shows the record, from April 20 to May 1, 2001, of the internal and external temperatures, and the difference between these temperatures. The bars at the top indicate luminosity: black for its absence, gray for its presence. From 0:00 h of day 20 to 9:00 h of day 24, the bees controlled the temperature, as revealed by the internal temperature and the difference in temperatures. At 9:30 h of April 24, a clear and sudden increase internal temperature of the indicated invasion of the hollow tree by an intruder. The internal temperature oscillated between $32.76^{\circ} \mathrm{C}$ and $36.13^{\circ} \mathrm{C}$ in the first cycle, $33.17^{\circ} \mathrm{C}$ and $37.00^{\circ} \mathrm{C}$ in the second cycle, and $33.17^{\circ} \mathrm{C}$ and $35.27^{\circ} \mathrm{C}$ in the third cycle, always with nocturnal peaks. The peaks are best visualized through the temperature difference. The greatest internal temperatures occurred during the night. At 15:00 h on April 27, an internal temperature decrease demonstrated intruder exit from the hollow tree. The internal temperature fell to a similar level as the external temperature and remained stable. 


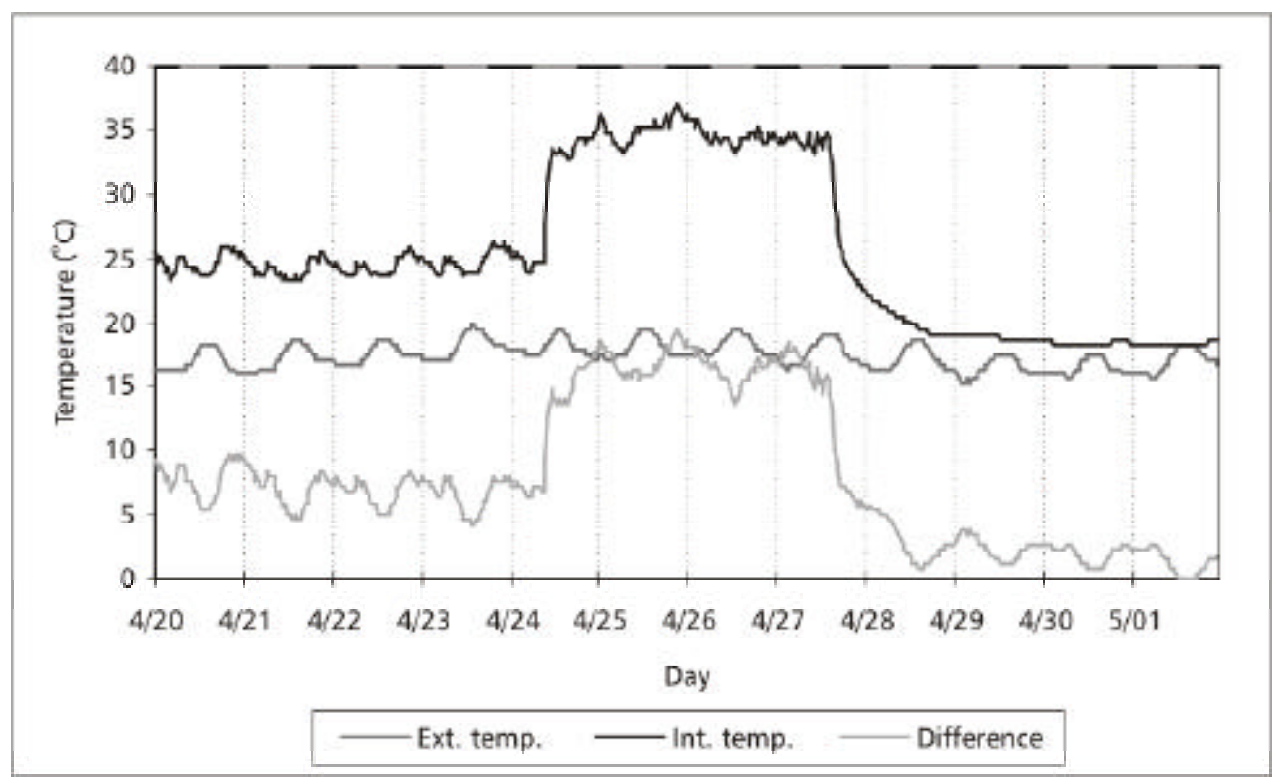

Fig. 1 - Time series of internal and external temperatures, and difference between these temperatures of the hollow tree, recorded at 30-minute intervals, for 12 days.

The Fig. 2 shows the hourly variation of the internal temperature inside the tree during three days for each situation. The environmental temperature cycles oscillated similarly in the three situations, between $15.23^{\circ} \mathrm{C}$ and $19.81^{\circ} \mathrm{C}(17.30 \pm 0.99)$, supporting analyzing them comparatively. Highly significant differences, however, were found between the internal and external temperatures (with bees: $t=$ 65.129, d.f. $=143, p<0.001$; with intruder: $t=$ 156.839, d.f. $=143, p<0.001$; empty: $t=23.913$, d.f. $=143, p<0.001$ ). The three situations themselves were significantly different from each other (beesintruder: $t=49.670, d . f .=143, p<0.001$; intruderempty hollow: $t=89.357$, d.f. $=143, p<0.001$; bees-empty hollow: $t=72.559$, d.f. $=143, p<0.001$ ).

Intruder presence caused the register of temperatures from $32.76^{\circ} \mathrm{C}$ to $37.00^{\circ} \mathrm{C}$ inside the hollow, with nocturnal temperature peaks during the three days of occupation. This range of relatively constant temperatures in relation to the environment occurs only for endothermic animals (Willmer et al.,
2000). We can, therefore, affirm from the evidence that the intruder was a small mammal, predominantly nocturnal, that takes shelter in burrows and probably feeds on bees and/or honey. Table 1 shows the heat production rates for day and night situations for mammal mass values from $750 \mathrm{~g}$ to $2000 \mathrm{~g}$.

\section{DISCUSSION}

Endothermy, associated with increased aerobic capacity and the insulation afforded by feathers and fur, enables birds and mammals to sustain relatively high activity levels for extended periods of time. This makes possible their migration and occupation of nocturnal niches and environments with highly variable thermal conditions, generally unavailable to ectothermic vertebrates (Ruben, 1996). The species tayra (Eira barbara), South American coati (Nasua nasua), giant anteater (Myrmecophaga tridactyla), and collared anteater (Tamandua tetradactyla), would probably not invade a bee nest due to their large sizes. 


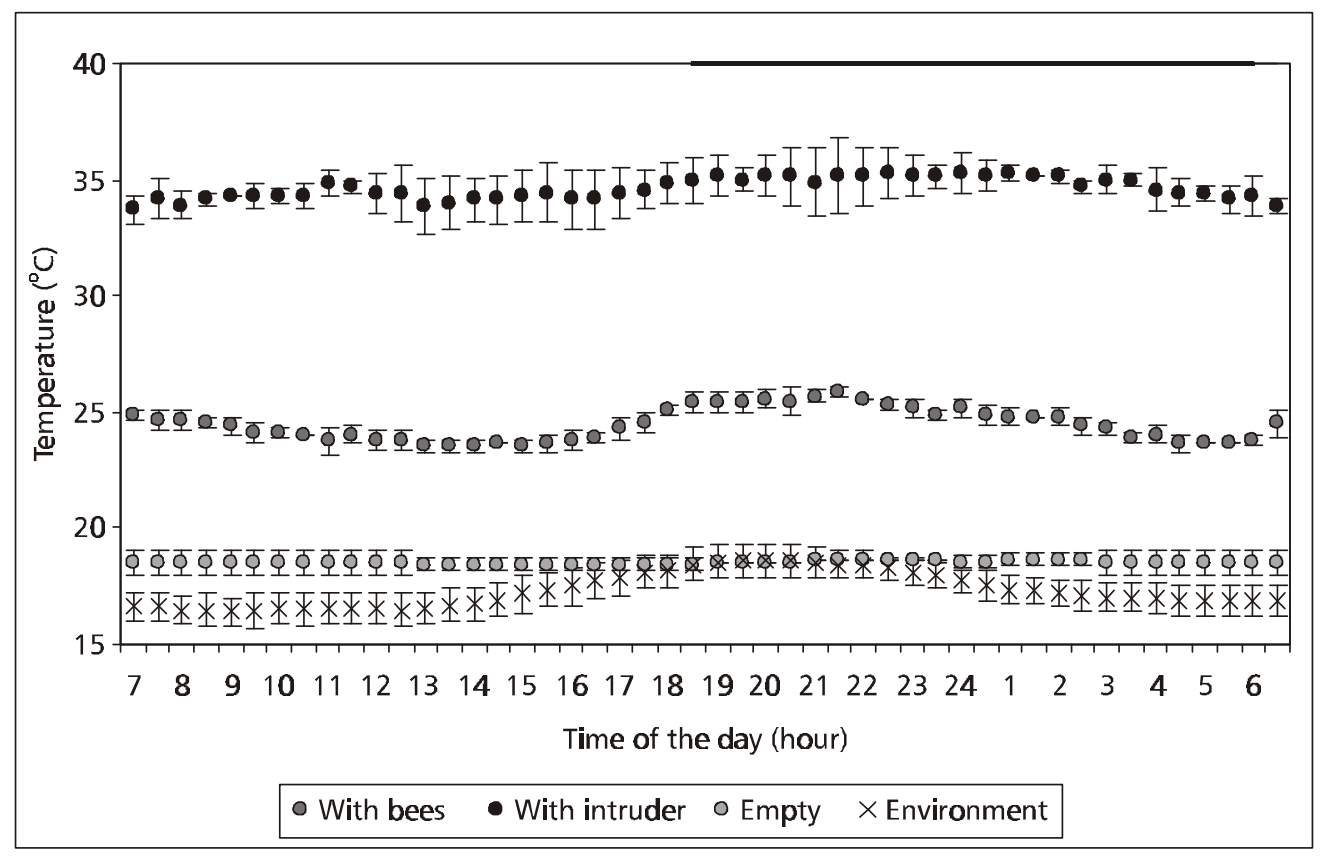

Fig. 2 - Average variation of internal temperatures over three days, in three situations: before, during, and after invasion (bars represent standard deviations).

TABLE 1

Heat production rate simulations for some body masses during te day and the night.

\begin{tabular}{|c|c|c|}
\hline Body mass (g) & $\begin{array}{c}\text { Heat production }(\mathbf{W} / \mathbf{k g}) \\
\text { during day rate }\end{array}$ & $\begin{array}{c}\text { Heat production }(\mathbf{W} / \mathbf{k g}) \\
\text { during night rate }\end{array}$ \\
\hline 750 & $4.7( \pm 0.3)$ & $4.9( \pm 0.3)$ \\
\hline 1000 & $4.2( \pm 0.3)$ & $4.4( \pm 0.3)$ \\
\hline 1250 & $3.8( \pm 0.3)$ & $4.0( \pm 0.3)$ \\
\hline 1500 & $3.5( \pm 0.2)$ & $3.7( \pm 0.2)$ \\
\hline 1750 & $3.3( \pm 0.2)$ & $3.4( \pm 0.2)$ \\
\hline 2000 & $3.1( \pm 0.2)$ & $3.3( \pm 0.2)$ \\
\hline
\end{tabular}

Moreover, they remain in burrows for no longer than $24 \mathrm{~h}$. Bare-tailed wooly, southern, Brazilian gracile mice, and gray four-eyed, threestriped, and gray short-tailed opossums (Caluromys philander, Didelphis aurita, Gracilinanus microtarsus, Philander opossum, Monodelphis americana, $M$. domestica, respectively) inhabit any hole that they find. However, they are mainly arboreal and there is no citation identifying them as burrowing animals. The opossums stay at the entrance of bee nests, eating them (Roubik, 1989). Moreover, they are very active, travelling long distances during the night. They may rest in shelters for days but only when cold is very intense. 
Among the suspects, the black rat (Rattus rattus) is only found next to human settlements and not in neotropical rainforests. The water rat (Nectomys squamipes) is a burrowing rat, which make nests under logs or roots or in dense vegetation. Generally, it lives in nests, of grass or leaves near water, with several entrances. The armadillos are the main suspects of the invasion, due to their size, diet, nocturnal habits, and because they take shelter in burrows. However, the great naked-tailed armadillo (Cabassous tatouay) seems to use burrows for one night only. The nine-banded long-nosed armadillo (Dasypus novemcinctus) is very abundant, but it excavates burrows with several entrances. The seven-banded long-nosed armadillo (Dasypus septemcinctus) seems to be rare in rainforests. The yellow armadillo (Euphractus sexcinctus) fulfills all the requirements and perhaps the intruder was of this species. At the Department of Zoology (IB-USP), there is a smaller-size specimen of this species (about $30.0 \mathrm{~cm}$ in head and body length) than that cited by Grzimek (1990) and Emmons \& Feer (1990), which would fit perfectly in the bee nest.

The body temperature regulation of the xenarthrans (sloths, tamanduas, and armadillos) is reminiscent of that of reptiles: to a certain extent, body temperature depends on environmental temperature. In two species of armadillo (nine-banded and southern three-banded armadillos), body temperature remains at $32^{\circ} \mathrm{C}$ when the external temperature oscillates from $16^{\circ} \mathrm{C}$ to $18^{\circ} \mathrm{C}$ (Grzimek, 1990). Environmental temperature in the three days of invasion oscillated from $16.38^{\circ} \mathrm{C}$ to $19.42^{\circ} \mathrm{C}$, and the temperature inside the hollow oscillated from $32.76^{\circ} \mathrm{C}$ to $37.00^{\circ} \mathrm{C}$.

Melipona subnitida, similar in size to $M$. bicolor, nests in trees and trunks with diameters ranging from $9.0-82.0 \mathrm{~cm}$. Internal diameter and height of six M. subnitida nests varied from 5.0 to $13.0 \mathrm{~cm}$ and from 63.0 to $150.0 \mathrm{~cm}$, respectively (Martins et al., 2001). However, there was no mention of the diameter of these six trees. Melipona beecheii, also comparable in size to $M$. bicolor, nests in logs with diameters ranging from $17.0-34.0 \mathrm{~cm}$; cavity diameter varies from 8.0 to $19.0 \mathrm{~cm}$ (van Veen \& Arce, 1999). Based on its diameter tree, we conclude that the hollow tree was about 15.0-35.0 $\mathrm{cm}$ wide. This space was enough for a mammal of around $15.0-35.0 \mathrm{~cm}$, with a body mass of from 750 $\mathrm{g}$ to $2000 \mathrm{~g}$.

The rate of heat production increased from $4.5 \%$ to $19.7 \%$ at night (considering standard deviation) when the animal was probably eating. These values (Table 1) are very close to those mentioned for the armadillo Dasypus novemcinctus (Mercer \& Hammel, 1989) whose core sensitivity was measured by subjecting individuals to total-body cooling at $5^{\circ} \mathrm{C}, 25^{\circ} \mathrm{C}$, and $35^{\circ} \mathrm{C}$, after exposure at $30^{\circ} \mathrm{C}$. The values obtained varied from $3.1 \mathrm{~W} / \mathrm{kg}$ to $5.5 \mathrm{~W} / \mathrm{kg}, 1.8 \mathrm{~W} / \mathrm{kg}$ to $4.2 \mathrm{~W} / \mathrm{kg}$, and $1.3 \mathrm{~W} / \mathrm{kg}$ to $2.8 \mathrm{~W} / \mathrm{kg}$, respectively. All these experiments were performed during a period when the armadillo normally sleeps. Animal weights were from $3.5 \mathrm{~kg}$ to $5.0 \mathrm{~kg}$.

Body temperature of small rodents and armadillos oscillates from $35^{\circ} \mathrm{C}$ to $37^{\circ} \mathrm{C}$ and from $34^{\circ} \mathrm{C}$ to $36^{\circ} \mathrm{C}$, respectively. Core body temperature is $33-34^{\circ} \mathrm{C}$ for edentates, $36^{\circ} \mathrm{C}$ for opossums, and $37-38^{\circ} \mathrm{C}$ for small rodents (Willmer et al., 2000). This variation in temperatures demonstrates just how complex it is to identify the intruder by recording temperatures. Knowledge of the behavior of the animal is, therefore, also very important.

Thermal evidence and behavior suggested that the intruder could only be one of a few species. More precise identification could be made by collecting other evidence, such as feces and fur.

Note: After the conclusion of this work, Luís Costa (inhabitant of Cunha, SP) informed us that the hollow tree was sequentially occupied by a nest of Melipona quadrifasciata, which was devastated by an animal (probably a small mammal). At the moment, it is occupied by a nest of Melipona bicolor. In order to bar potential predators without affecting the bees, Mr. Costa simply placed a rock covering the hole dug by the intruder.

Acknowledgments - We are grateful to Dr. Márcia F. Ribeiro for her comments. We are indebted to the referees (specially Dr. Warwick E. Kerr), who contributed to the improvement of this paper. We also thank CNPq (140169/2000-8) for financial support granted to $\mathrm{SDH}$. 


\section{REFERENCES}

BRADLEY, S. R. \& DEAVERS, D. R., 1980, A re-examination of the relationship between thermal conductance and body weight in mammals. Comp. Biochem. Physiol. - A Comp. Physiol., 65: 465-476.

CASTRO, M. S., 2001, A comunidade de abelhas (Hymenoptera; Apoidea) de uma área de caatinga arbórea entre os inselbergs de Milagres (12 53 'S; $39^{\circ} 51^{\prime} \mathrm{W}$ ), Bahia. Tese de Doutorado, Departamento de Ecologia, Instituto de Biociências, USP, São Paulo, 191p.

EMMONS, L. H. \& FEER, F., 1990, Neotropical rainforest mammals: a field guide. The University of Chicago Press, Chicago, 281p.

GRZIMEK, B. (ed.), 1990, Grzimek's encyclopedia of mammals. vols. I, II and III, McGraw-Hill Pub. Co., New York.

MARTINS, C. F., CORTOPASSI-LAURINO, M., KOEDAM, D. \& IMPERATRIZ-FONSECA, V. L., 2001, The use of trees for nesting by stingless bees in Brazilian caatinga. Proc. XXXVII, Int. Apicultural Congr., Durban, Doc. 341 (CDROM).

MERCER, J. B. \& HAMMEL, H. T., 1989, Total calorimetry and temperature regulation in the nine-banded armadillo. Acta Physiol. Scand., 135: 579-589.
NOGUEIRA-NETO, P., 1997, Vida e criação de abelhas indigenas sem ferrão. Editora Nogueirapis, São Paulo, 445p.

ROUBIK, D. W., 1989, Ecology and natural history of tropical bees. Cambridge Univ. Press, Cambridge, 514p.

RUBEN, J., 1996, Evolution of endothermy in mammals, birds and their ancestors, pp. 347-376. In: I. A. Johnston \& A. F. Bennett (ed.), Animals and temperature: phenotypic and evolutionary adaptation. Cambridge University Press, Cambridge.

VAN VEEN, J. W. \& ARCE, H. G. A., 1999, Nest and colony characteristics of log-hived Melipona beecheii (Apidae: Meliponinae). J. Apic. Res., 38(1-2): 43-48.

WILlMER, P. J., STONE, G. \& JOHNSTON, I., 2000, Environmental physiology of animals. Blackwell Science Ltd., Oxford, 666p.

WILSON, D. E. \& REEDER, M. D. (eds.), 1993, Mammal species of the world: a taxonomic and geografic reference. $2^{\text {nd }}$ ed., Smithsonian Institution Press, Washington, 1207p.

ZAR, J. H., 1999, Biostatistical analysis. $4^{\text {th }}$ ed., Prentice-Hall, Upper Saddle River, New Jersey, 718p. 